\title{
Effect of grazing strategies and pasture species on irrigated pasture beef production
}

\author{
JAMES T. NICHOLS, DAVID W. SANSON, AND DARREL D. MYRAN
}

\begin{abstract}
Authors are professor, agronomy (range and forage). West Central Research and Extension Center. University of Nebraska, North Platte 69101; ruminant nutrition specialist, University of Wyoming, Laramie 82071; and reclamation coordinator, Westmoreland Resources Inc., Hardin, Mont. 59034. At the time of the research, the second author was post-doctoral research technician (beef nutrition), and the third author was research technician (range and forage) at the West Central Research and Extension Center, University of Nebraska, North Platte.
\end{abstract}

\section{Abstract}

Irrigated cool-season grasses can be used as complementary forages with other forage resources. Improved efficiency of animal production from irrigated pasture could increase their utility as a complementary forage. The factors of species composition, grazing management, irrigation, and fertilization all have the potential to affect efficiency of irrigated pasture production. Specific objectives of this study were: (1) to determine the effect of deferring irrigated pasture and restricting irrigation water and fertilization during mid-summer on pasture and livestock production; and (2) to evaluate different pasture stands for adaptability to different grazing strategies. Eight, adjacent 1.25-ha pastures were established as 2 replications of 2 different pasture stands grazed under 2 grazing management strategies. Pasture stands consisted of intermediate wheatgrass (A gropyron intermedium Host. Beauv.) as a monoculture (IWG) and a 4-species mixture (MIX) of orchardgrass (Dactylis glomerata L.), smooth bromegrass (Bromus inermis Leyss.), meadow bromegrass (Bromus biebersteinii R. \& S.), and Garrison creeping foxtail (Alopercurus arundinaceus Poir.). Grazing treatments with yearling steers consisted of season-long grazing (SLG) and a graze-defer-graze (GDG) strategy. For the GDG pastures, $38 \%$ less fertilizer and $34 \%$ less irrigation water were applied, but animal days of grazing were reduced only $16 \%$ over the 3 -year study. Animal weight gains were comparable between pasture types when considered over the entire grazing season but were higher for IWG early in the growing season and for MIX late in the season. Persistence of pasture stand was better for the MIX pastures than IWG pastures which were invaded by annual weeds after the first grazing season. Highest gains $\mathrm{ha}^{-1}$ were from the SLG pastures because of more days of grazing, but animal productivity was not proportionally reduced for the GDG strategy. The MIX pastures were suited for either grazing strategy.

Key Words: animal gain, forage quality, carrying capacity, complementary forage

In many areas of the Great Plains, irrigated pasture of coolseason grasses can increase the forage options available to livestock producers. Cool-season pastures permit development of complementary forage systems with associated rangeland and other forage resources. Complementary forage systems have the potential to increase production per unit of land, improve animal performance, provide an alternative to harvested feeds, and increase forage availability during drought (Nichols 1989). The impact of using complementary forages with range has been documented (Allen 1972, Anderson and Jernstedt 1971, Ford et al. 1986, Hart et al. 1988, Lodge 1963, Mcllvain and Shoop 1973,

\footnotetext{
Published as Paper \#9311, Journal Series, University of Nebraska Agricultural Research Division.

Manuscript accepted I Aug. 1992
}

Moore 1970, Smoliak 1968). However, management practices used and type of forage resources considered are highly variable depending on locality and goals of the producer. Irrigated cool-season grasses are a viable complementary forage in many areas of the Great Plains because of the associated rangeland dominated by warm-season grasses.

Animal production can be high from irrigated cool-season grasses under excellent management. Animal gain exceeded $800 \mathrm{~kg}$ $\mathrm{ha}^{-1}$ in $\mathbf{1 3}$ out of 35 trials at 10 different locations (Nichols and Clanton 1985). A major constraint to greater use of irrigated pasture has been high production cost in relation to other forage resources, not their productivity or utility as a complementary forage. Based on a projected level of production of 30 animal units months (AUM) ha ${ }^{-1}$, total costs per AUM in southwest Nebraska have been estimated at $\$ 22.20$ (Agricultural Economics Staff 1991). This production level represents the upper limits that can be achieved with season-long grazing under excellent grazing management with high water and fertilizer applications (Nichols and Clanton 1985).

A previous study at North Platte, Neb., has shown that the least efficient period for animal production from irrigated cool-season grasses was during mid-summer when pasture and animal production declined, but irrigation water and fertilizer requirements remained high in order to stimulate pasture production (Nichols and Moore 1977). Cool-season grasses decline in productivity during periods of high ambient temperature. This factor has a major impact on the overall efficiency of irrigated pasture. If this period of decreased pasture productivity and efficiency could be circumvented by using other forages, the positive aspects of irrigated, cool-season grasses as a component of a complementary forage system could be improved.

The objectives of this study were to compare pasture and animal production from irrigated pasture seeded to different pasture species which were grazed season-long, compared to deferred during mid-summer without irrigation or fertilization.

\section{Methods and Materials}

The study area was located on the University of Nebraska West Central Research and Extension Center at North Platte. Pastures were on nearly level class I land with deep, fertile soils classified as Cozad silt loam (Typic Haplustolla). Field plot design was a factorial arrangement of 2 pasture types under 2 summer grazing management strategies, replicated twice and conducted over 3 grazing seasons during 1985-87.

Eight adjacent, 1.25 ha irrigated pasture units were randomly assigned to 2 replications of 2 types of pasture and seeded to: (1) a monoculture of 'Slate' intermediate wheatgrass (Agropyron intermedium Host. Beauv.) designated as IWG; and (2) a mixture (MIX) of 'Sterling' orchardgrass ( Dactylis glomerata L.), 'Lincoln' 
Table 1. Precipitation (Mar.-Sept.), irrigation water, and fertilizer for season-long (SLG) and graze-defer-graze (GDG) grazing strategies.

\begin{tabular}{|c|c|c|c|c|c|}
\hline \multirow[b]{2}{*}{ Year } & \multirow[b]{2}{*}{ Precipitation } & \multicolumn{2}{|c|}{ Irrigation } & \multicolumn{2}{|c|}{ Nitrogen } \\
\hline & & SLG & GDG & SLG & GDG \\
\hline & -mm- & \multicolumn{2}{|c|}{$-\mathrm{mm}$} & \multicolumn{2}{|c|}{$-\mathrm{kg} \mathrm{ha}^{-1}$} \\
\hline 1 & 287 & 297 & 198 & 290 & 180 \\
\hline 2 & 401 & 315 & 178 & 290 & 180 \\
\hline 3 & 386 & 290 & 221 & 290 & 180 \\
\hline Average & 358 & 300 & 198 & 290 & 180 \\
\hline
\end{tabular}

smooth bromegrass (Bromus inermis Leyss.), 'Regar' meadow bromegrass ( Bromus biebersteinii R. \& S.), and 'Garrison' creeping foxtail (Alopercurus arundinaceus Poir.). Seeding rates (pure live seed basis) were 25 and $18 \mathrm{~kg} \mathrm{ha}^{-1}$ for IWG and MIX, respectively. Results from an earlier study which evaluated 8 grasses for irrigated pasture were used as a basis for the selection of plant materials for this study (Nichols et al. 1976). Pastures were planted in late August of 1984 and grazing commenced in May of 1985. Excellent stands were established on both pasture types when grazing trials commenced.

Within each pasture type, 2 summer grazing management strategies were randomly assigned: (1) season-long grazing (SLG); and (2) a graze-defer-graze (GDG) strategy. Season-long grazing consisted of maintaining steers on irrigated pasture for the 148-day grazing season starting about 1 May. The graze-defer-graze treatment was identical, with the exception that steers were removed from irrigated pasture during the summer deferment period. The grazing season was divided into 3 periods for data collection, which corresponded to the pasture management strategy for the GDG treatment. During period I, all pastures were grazed for 60 days. During period II, all cattle assigned to the GDG treatment were removed from pasture and put on a subirrigated meadow site for 56 days which was lush and immature and considered to be similar to forage on the study site. All pastures were grazed during period III for 32 days.

Crossbred yearling steers with an average initial live weight of $275 \mathrm{~kg}$ were used to evaluate the different pasture treatments. Steers were adapted to similar forage for 14 days before being placed on the test pastures. Stocking rates were 10 steers/pasture unit $\left(8 \mathrm{head} \mathrm{ha}^{-1}\right)$ during year 1 and 8 steers $\left(6.42 \mathrm{head} \mathrm{ha}^{-1}\right)$ for years 2 and 3 . This initial base stocking rate was maintained on all pastures throughout the grazing periods. These steers were designated as "tester" steers from which average daily gain (ADG) was calculated from weights taken at the start of the grazing season and at the end of each period following 16 hours without feed and water. A group of similar steers was maintained on extra irrigated pasture of the same forage species and used as "put and take" animals for regulating forage availability. Steer days of grazing from the "put and take" group were added to steer days from the "tester" group for total animal days ha ${ }^{-1}(\mathrm{ADH})$, but were not used for calculation of ADG. Weight gain ha ${ }^{-1}$ (WGH) was calculated as ADG $\times$ ADH. Procedures and computations essentially follow those suggested by Mott (1959) and summarized by Matches (1970).

Each pasture unit was rotationally grazed in 5 equal-size paddocks, $(0.25 \mathrm{ha})$ divided by single-strand electric fence. Rotation of steers among paddocks was flexible, but was generally on a 5- to 7-day basis, which allowed 25 to 28 days for pasture recovery. Relative forage availability was estimated daily for all pastures. Since the entire experimental area was small (10-25 ha), ocular estimates of forage availability could be readily made by comparing forage height and mass. Steers from the "put and take" group were placed on pasture to maintain comparable forage availability among treatment pastures. Steers were moved to a fresh paddock when only about $60 \%$ of the forage was utilized in order to allow the steers a high degree of selectivity and to maintain pasture productivity.

Irrigation was by solid-set, sprinkler irrigation which watered each treatment pasture independently. Irrigation was used to supplement natural precipitation to maintain near optimum grass growth. The soil water status was monitored by gravimetric sampling. All pastures received equal irrigation amounts throughout the growing season with the exception of GDG pastures, which were not irrigated during period II. Difference in total irrigation water applied to the grazing strategies is presented in Table 1 . One week before the start of grazing for period III, irrigation water was applied to the GDG pastures to equalize the soil water status among the treatment pastures.

Nitrogen fertilizer was applied equally across all pastures with the exception of period II. Total nitrogen $(\mathrm{N})$ applied each year was $290 \mathrm{~kg} \mathrm{ha}^{-1}$ for the SLG pasture and $180 \mathrm{~kg} \mathrm{ha}^{-1}$ for the GDG pasture (Table 1). Granular, ammonium nitrate $\left(\mathrm{NH}_{4} \mathrm{NO}_{3}\right)$ was

Table 2. Average daily gain (kg) of steers grazing pastures seeded to either a mixture of 4 species (MIX) or intermediate wheatgrass (IW G) and grazed either season long (SLG) or graze-defer-graze (GDG).

\begin{tabular}{|c|c|c|c|c|c|c|c|}
\hline \multirow[b]{2}{*}{ Period } & \multicolumn{3}{|c|}{ Pasture type } & \multicolumn{3}{|c|}{ Management strategy } & \multirow[b]{2}{*}{ SEM $^{1}$} \\
\hline & MIX & IWG & $\mathbf{P}>\mathrm{F}$ & SLG & GDG & $\mathrm{P}>\mathrm{F}$ & \\
\hline Year 1 & 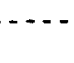 & --- & $\cdots$ & - (kg) - & -- & $\cdots--$ & $\cdots$ \\
\hline $\begin{array}{l}\text { I } \\
\text { II }^{2} \\
\text { III } \\
\text { Cumulative }\end{array}$ & $\begin{array}{l}1.06 \\
0.70 \\
0.72 \\
0.89\end{array}$ & $\begin{array}{l}1.98 \\
0.68 \\
0.73 \\
0.93\end{array}$ & $\begin{array}{l}0.022 \\
0.798 \\
0.920 \\
0.186\end{array}$ & $\begin{array}{c}1.20 \\
(0.69) \\
0.80 \\
0.91\end{array}$ & $\begin{array}{c}1.06 \\
(0.85) \\
0.65 \\
0.90\end{array}$ & $\begin{array}{c}0.025 \\
- \\
0.101 \\
0.660\end{array}$ & $\begin{array}{l}0.06 \\
0.13 \\
0.11 \\
0.04\end{array}$ \\
\hline $\begin{array}{l}\text { Year } 2 \\
\text { I } \\
\text { II }^{2} \\
\text { III } \\
\text { Cumulative }\end{array}$ & $\begin{array}{l}0.44 \\
0.96 \\
0.60 \\
0.70\end{array}$ & $\begin{array}{l}0.56 \\
0.84 \\
0.44 \\
0.68\end{array}$ & $\begin{array}{l}0.184 \\
0.104 \\
0.089 \\
0.687\end{array}$ & $\begin{array}{c}0.55 \\
(0.92) \\
0.64 \\
0.71\end{array}$ & $\begin{array}{c}0.44 \\
(0.106) \\
0.41 \\
0.67\end{array}$ & $\begin{array}{c}0.226 \\
- \\
0.030 \\
0.405\end{array}$ & $\begin{array}{l}0.12 \\
0.08^{3} \\
0.11 \\
0.06\end{array}$ \\
\hline $\begin{array}{l}\text { Year } 3 \\
\text { I } \\
\text { II }^{2} \\
\text { III } \\
\text { Cumulative }\end{array}$ & $\begin{array}{l}0.50 \\
0.94 \\
0.84 \\
0.79\end{array}$ & $\begin{array}{l}0.59 \\
0.68 \\
0.64 \\
0.72\end{array}$ & $\begin{array}{l}0.083 \\
0.032 \\
0.029 \\
0.088\end{array}$ & $\begin{array}{c}0.58 \\
(0.82) \\
0.86 \\
0.73\end{array}$ & $\begin{array}{c}0.53 \\
(1.11) \\
0.62 \\
0.77\end{array}$ & $\begin{array}{c}0.246 \\
- \\
0.017 \\
0.317\end{array}$ & $\begin{array}{l}0.06 \\
0.07 \\
0.10 \\
0.05\end{array}$ \\
\hline
\end{tabular}

'Standard error of the mean.

2Statistical analysis included only average daily gain of steers on SLG. Values under management strategy columns are for information only. 
applied to all pastures before "green up" in the spring at the rate of $56 \mathrm{~kg} \mathrm{ha}^{-1}$. This was followed by $20 \mathrm{~kg} \mathrm{ha}^{-1}$ applications of $28 \% \mathrm{~N}$ solution as urea-ammonium nitrate $\left[\left(\mathrm{NH}_{2}\right)_{2} \mathrm{CO} \bullet \mathrm{NY}_{4} \mathrm{NO}_{3}\right]$ through the irrigation system when irrigating on about 10-day intervals. Laboratory soil analyses did not indicate a need for other nutrients during the study period.

Statistical procedures used were SAS (1985). Period I, period III, and trial ADG, ADH, and WGH data were analyzed using a model appropriate for a replicated $2 \times 2$ factorial design. The initial model included main effects for pasture type, grazing management and year, and the associated interactions, as well as pasture type by grazing management within replicate. This term was used as the error term for testing pasture type, grazing management, and their interaction. A significant year effect $(P<0.05)$ was observed for each parameter; therefore, data were subsequently analyzed within each year using a model including pasture type, grazing management, and the associated interaction. A significant pasture type by grazing management interaction was present for ADH for period I and trial data; therefore, simple effects were analyzed using a completely randomized design with separation of means by protected least significant difference. Animals on the GDG treatment were removed from the study during period II; therefore, data from this period was analyzed as a completely randomized design using only the data from the SLG treatment.

\section{Results}

The experimental design of the study stipulated that no fertilizer or irrigation water be applied to the GDG treatment during period II when grazing was deferred. This resulted in $38 \%$ less total nitrogen and $34 \%$ less irrigation water applied over the grazing season each year compared to the SLG pasture (Table 1). The reduction of these 2 primary production inputs in relation to the overall pasture productivity is important in evaluating the feasibility of the practices. Costs associated with these inputs would be highly variable depending on irrigation and fertilization practices and prices and should be evaluated on an individual ranch or farm basis. In addition, if the economics are viewed within the context of a production system, the forage resources grazed during the deferment period could include many different forage options, which would have a major impact on overall pasture and animal production.

\section{Average Daily Gains}

Significant year by treatment interactions $(P<0.01)$ were present over all periods for ADG; however pasture type by grazing management interaction was not present $(P>0.40)$. The distribution pattern of steer gains over the entire growing season was influenced by pasture type (Table 2). In year 1 , steers grazing IWG gained $86 \%$ more during the early growing season (period I) than steers grazing MIX, but as the growing season progressed, there were no differences between pasture types during the last 2 grazing periods. The tendency for better steer gains for IWG during period I continued for years 2 and 3, but differences became less pronounced between pasture types. By mid-season there was a shift to better animal gains from MIX. Average daily gain was higher during the periods II and III for MIX than IWG pastures for years 2 and 3 . Average daily gains for MIX were 14 and $36 \%$ higher for periods II and II respectively for year 2, and 38 and $31 \%$ higher for the same periods for year 3. Cumulative ADG was not different for years 1 or 2, but the MIX pastures produced higher gains during year 3 . When considering steer performance over the entire growing season, the change from better gains early by IWG to better gains mid to late season by MIX tended to mask any differences in animal performance by periods between the 2 pasture types.

Based on animal performance, these data indicated that IWG provided a higher quality forage during the early part of the growing season, whereas MIX pastures produced a better quality forage during the mid to late part of the growing season. The fact that management practices and forage availability were similar for both pasture types supports this interpretation.

The effects of management strategy on steer performance were not different $(P>0.86)$ over the 3-year study. Overall ADG for each year was not different between SLG and GDG for any of the 3 years, but there were significant effects associated with time of grazing (periods) within a specific year (Table 2). Season-long grazing produced higher $A D G$ during period $I$ of the first year, but not during succeeding years.

The most obvious differences in steer performance were for period III. Steers on the GDG pastures gained $0.15,0.23$, and 0.24 $\mathrm{kg} \mathrm{day}^{-1}$ less than steers on the SLG pastures for years 1,2 , and 3, respectively (Table 2 ). These lower gains were considered a response to higher gains realized during period II when the GDG steers were rotated off the test pasture to a lightly stocked subirrigated meadow during the deferment period. Evidently, a higher quality diet and/or increased forage intake was realized by the steers on the subirrigated meadow during period II which had a negative effect on gains during period III. Mean weight gains for management strategies are shown in parentheses in Table 2, but were not considered part of the treatments and were not included in the analyses.

Based on these data, it would not be anticipated that grazing strategy alone would have an effect on steer gains while on irrigated pastures. If steers were rotated from irrigated pasture during the deferment period to other forages (either higher of lower in quality), a differential response in steer gains could be anticipated when rotated back to irrigated pasture.

\section{Animal Days/Hectare}

Total animal days of grazing (animal number $X$ days grazed) provided a measure of pasture productivity as affected by pasture type and grazing strategy. A pasture type by grazing strategy interaction $(P<0.05)$ was present overall and for period III; therefore, simple effect means are presented for each year and period (Table 3). Total ADH was higher during years 1 and 3 for the SLG management strategy than for GDG over both pasture types (Table 3). During year 2, total ADH was higher for the SLG-MIX

Table 3. Animal days ha-1 (ADH) simple effect means for pastures seeded to either a mixture of 4 species (MIX) or intermediate whestgrass (IWG) and grazed either season long (SLG) or grazed-defer-graze (GDG).

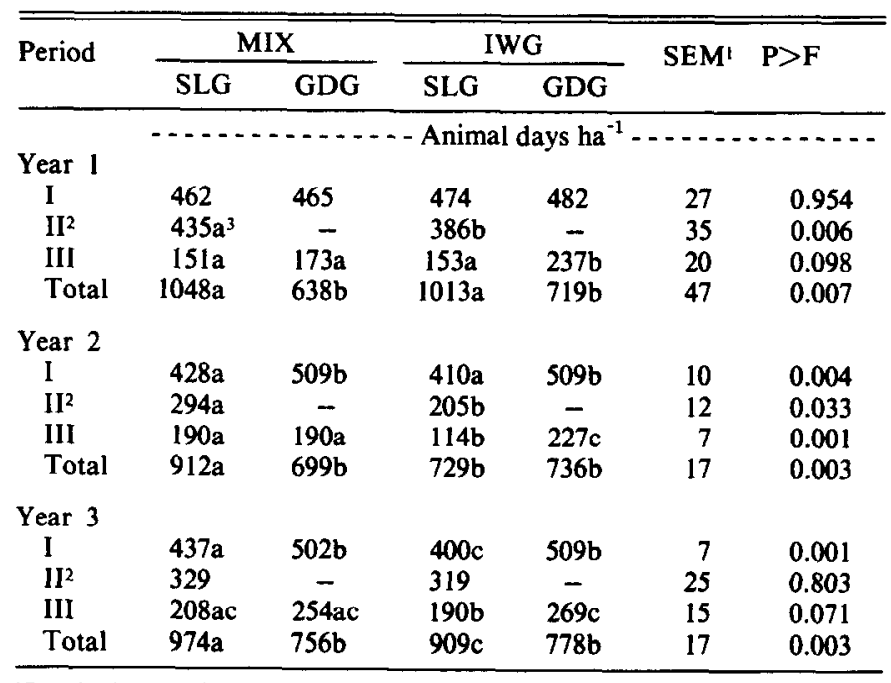

'Standard error of the mean.

2Statistical analysis includes only ADH for SLG.

${ }^{3}$ Row means with different letters differ $(P<.05)$. 
Table 4. Weight gain $\left(\mathrm{kg} \mathrm{ha}^{-1}\right)$ from pastures seeded to a mixture of 4 species (MIX) or intermediate wheatgrass (IWG) and grazed either season long (SLG) or graze-defer-graze (GDG) for 3 years.

\begin{tabular}{|c|c|c|c|c|c|c|c|}
\hline \multirow[b]{2}{*}{ Period } & \multicolumn{3}{|c|}{ Pasture type } & \multicolumn{3}{|c|}{ Management strategy } & \multirow[b]{2}{*}{ SEM ${ }^{1}$} \\
\hline & MIX & IWG & $\mathbf{P}>\mathrm{F}$ & SLG & GDG & $P>F$ & \\
\hline & $\cdots$ & $\cdots$ & $\cdots$ & $\mathrm{kg} / \mathrm{ha}$ & $\cdots$ & $\ldots$. & $\ldots \ldots$ \\
\hline \multicolumn{8}{|l|}{ Year 1} \\
\hline I & 475 & 554 & 0.042 & 542 & 486 & 0.100 & 17 \\
\hline $\mathrm{II}^{2}$ & 352 & 253 & 0.101 & $(274)$ & - & - & 16 \\
\hline III & 112 & 137 & 0.175 & 119 & 130 & 0.471 & 10 \\
\hline Total & 939 & 944 & 0.168 & 935 & 616 & 0.003 & 31 \\
\hline \multicolumn{8}{|l|}{ Year 2} \\
\hline I & 196 & 245 & 0.269 & 223 & 218 & 0.908 & 24 \\
\hline $\mathrm{II}^{2}$ & 282 & 168 & 0.045 & $(227)$ & - & - & 16 \\
\hline III & 112 & 63 & 0.022 & 95 & 80 & 0.303 & 8 \\
\hline Total & 590 & 476 & 0.280 & 545 & 298 & 0.006 & 28 \\
\hline \multicolumn{8}{|l|}{ Year 3} \\
\hline I & 230 & 261 & 0.129 & 233 & 258 & 0.233 & 10 \\
\hline $\mathrm{II}^{2}$ & 301 & 211 & 0.045 & $(257)$ & - & - & 18 \\
\hline III & 185 & 137 & 0.010 & 166 & 156 & 0.432 & 7 \\
\hline Total & 716 & 609 & 0.001 & 656 & 414 & 0.001 & 5 \\
\hline
\end{tabular}

IStandard error of the mean.

2Statistical analysis included only weight gain of steers on SLG. Values under management strategy are for information only.

treatment than the other combinations. No differences were observed among SLG-IWG and the 2 pasture types that were deferred. Pasture productivity would be expected to be higher for the SLG steers since they grazed an extra 56 days during period II when the steers on the GDG management strategy were removed from the study and grazed on subirrigated meadows.

For year 1, there were no differences in total ADH between pasture types when grazed under either grazing treatment. Since the first year of grazing was on stands that were established the previous fall, this probably does not reflect potential differences between pasture types. However, by years 2 and 3, MIX pastures produced 183 and 65 more ADH, respectively, than IWG when grazed season-long. Under GDG, there were no significant differences between pasture types for either year 2 or 3 .

When ADH for SLG for period II was subtracted from the total to equalize time on pasture, the total grazing capacity for GDGMIX was increased over SLG-MIX by 4, 13, and $17 \%$ for years 1,2 , and 3, respectively. The GDG strategy with IWG increased the total grazing capacity over SLG by 15,41 , and $32 \%$ over the same year sequence.

In general, these data suggested that MIX was more productive than IWG under SLG, but there was no difference under GDG. The GDG management strategy increased the grazing capacity for both MIX and IWG when ADH were equalized.

\section{Animal Gains/Hectare}

The animal gains ha ${ }^{-1}$ (AGH) shown in Table 4 are a product of ADG and ADH and thus reflect in one value the total pasture productivity. Gains of steers while on subirrigated meadow pasture (period II) were not included in total pasture production values. Year by treatment interaction $(P<0.03)$ indicated that animal gains could be expected to be variable among years depending on grazing strategy and/or pasture stand. There was no pasture type by management strategy interaction $(P<0.05)$.

Although significant only for the first period in year 1, IWG tended to produce more AGH than MIX during the early portion of the growing season for all years (Table 4). However, for periods II and III, AGH from MIX exceeded gain from IWG by 114 and 49 $\mathrm{kg} \mathrm{ha}^{-1}$ for year 2 , and by 90 and $48 \mathrm{~kg} \mathrm{ha}^{-1}$ for year 3 , respectively. The seasonal distribution pattern of $\mathrm{AGH}$ as affected by pasture type was similar to trends indicated for both animal performance and pasture production which was previously discussed. This would be expected since AGH is a produce of these values.
The significant increase in total AGH for the SLG management strategy resulted from the gain realized during Period II when the steers were removed from the GDG pastures and placed on subirrigated meadow (Table 4). With the exception of Period I, year 1, there were no differences between grazing strategies for Periods I and III. Discounting the gain from the SLG pastures during Period II resulted in no effect of grazing strategy on AGH when considered over the grazing season.

\section{Pasture Persistence}

Visual observations indicated that weedy species were becoming a severe problem in the IWG pastures after the first grazing season. Yellow foxtail (Setaria lutescense Weig.), green foxtail (Setaria viridis L.), and redroot pigweed (Amaranthus retroflexus L.) increased each year of the study, becoming most abundant during year 3 . In contrast, MIX pastures maintained excellent grass stands throughout the study resisting invasion of weedy species and persisting equally well under both grazing management strategies.

\section{Discussion and Conclusions}

Carrying capacity and animal gain were highest for the SLG grazing strategy, primarily due to the extra 56 days of grazing, while the GDG steers were off the test pastures on subirrigated meadow forage. Fertilizer and irrigation water were reduced by 38 and $34 \%$, respectively, for the GDG pastures during this period, but the total carrying capacity was reduced only $16 \%$ over the 3-year study. These data indicate that the season-long production efficiency of irrigated pasture could be improved by removing steers from irrigated pasture and eliminating irrigation and fertilization during mid-summer when the productivity of cool-season grasses declines. The GDG practice fits within the concept of using alternative forage resources during different segments of the growing season when each are most productive, which was described by Mcllvain and Shoop (1973) as a "complementary forage system."

A comparison of MIX and IWG pasture stands in relation to grazing strategy indicated that animal performance was comparable overall, but that steer gains on IWG were generally higher early in the growing season, whereas MIX pastures produced better gains late in the grazing season. Persistence of stands was better for the MIX pastures compared to IWG which became invaded by weedy species. Both ADG and AGH were higher for MIX than 
IWG. Under the conditions of this study, the MIX pastures were better adapted to either grazing strategy than the IWG pastures.

\section{Literature Cited}

Agricultural Economies Staff. 1991. Estimated crop and livestock production costs. Univ. Nebraska Coop. Ext. Ser. Pub. EC91-872. Lincoln, Neb. p. B13-14.

Allen, H.R. 1972. Grassland production systems compared with grain production. South Dakota State Univ. Agr. Exp Sta. Bull. 600. Brookings.

Anderson, W.E., and J.J. Jernstedt. 1971. Evaluating multiple economic effects of forage development and management. J. Range Manage. 24:174-180.

Ford, M.J., D.C. Clanton, and M.E. England. 1986. Computer simulation-retained ownership profitable. Univ. Nebraska Agr. Exp. Sta. Beef Cattle Rep. MP-50, Lincoln, Neb. p. 6-9.

Hart, R.E., J.W. Waggoner, Jr., T.G. Dunn, C.C. Kaltenbach, and L.D. Adams. 1988. Optional stocking rate for cow-calf enterprises on native range and complementary improved pastures. J. Range Manage. 41:435-440.

Lodge, R.W. 1963. Complementary grazing systems for Sandhills of the Northern Great Plains. J. Range Manage. 16:240-244.
Matches, A.G. 1970. Pasture research methods. Proc. Nat. Conf. Forage Qual. Eval. Util., Univ. Nebraska. Lincoln, Neb. Sect. I., p. 1-32.

McIlvain, E.H., and M.C. Shoop. 1973. Use of farmed and tame pasture to complement native range. Proc. Great Plains Beef Symposium, Lincoln, Neb. p. L, 1-19.

Moore, R.A. 1970. Symposium on pasture methods for maximum production: pasture systems for a cow-calf operation. J. Anim. Sci. 30:133-137.

Mott, G.0. 1959. Intersociety forage evaluation symposium: IV. Animal variation and measurement of forage quality. Agron. J. 51:223-226.

Nichols, J.T., M.J. Moore, L.F. Hoatson, and D.C. Clanton. 1976. Grasses for irrigated pasture. Univ. Nebraska Beef Cattle Rep. EC76-218. Lincoln. p. 12-13.

Nichols, J.T. 1989. Range, plus complementary forages for beef cattle production p. 196-203. In: Proc. Amer. Forage and Grassland Congr., Univ. Guelph, Ontario, Canada.

Nichols, J.T., and D.C. Clanton. 1985. Irrigated pastures, p. 507-516. In. M.E. Heath, R.F. Barnes, D.S. Metcalf (eds.) Forages, the Science of Grassland Agriculture, 4th ed. Iowa State Univ., Press, Ames.

Nichols, J.T., and M.J. Moore. 1977. Beef production and water use efficiency of eight irrigated pasture grasses. Proc. Irrigation Short Course, Jan. 24-25, 1977. Univ. Nebraska, Lincoln, Neb. p. 112-116.

SAS. 1985. SAS users guide: Statistics. SAS Inst. Inc., Cary, N.C.

Smoliak, S. 1968. Grazing studies on native range, crested wheatgrass and Russian wildrye pastures. J. Range Manage. 21:47-50.

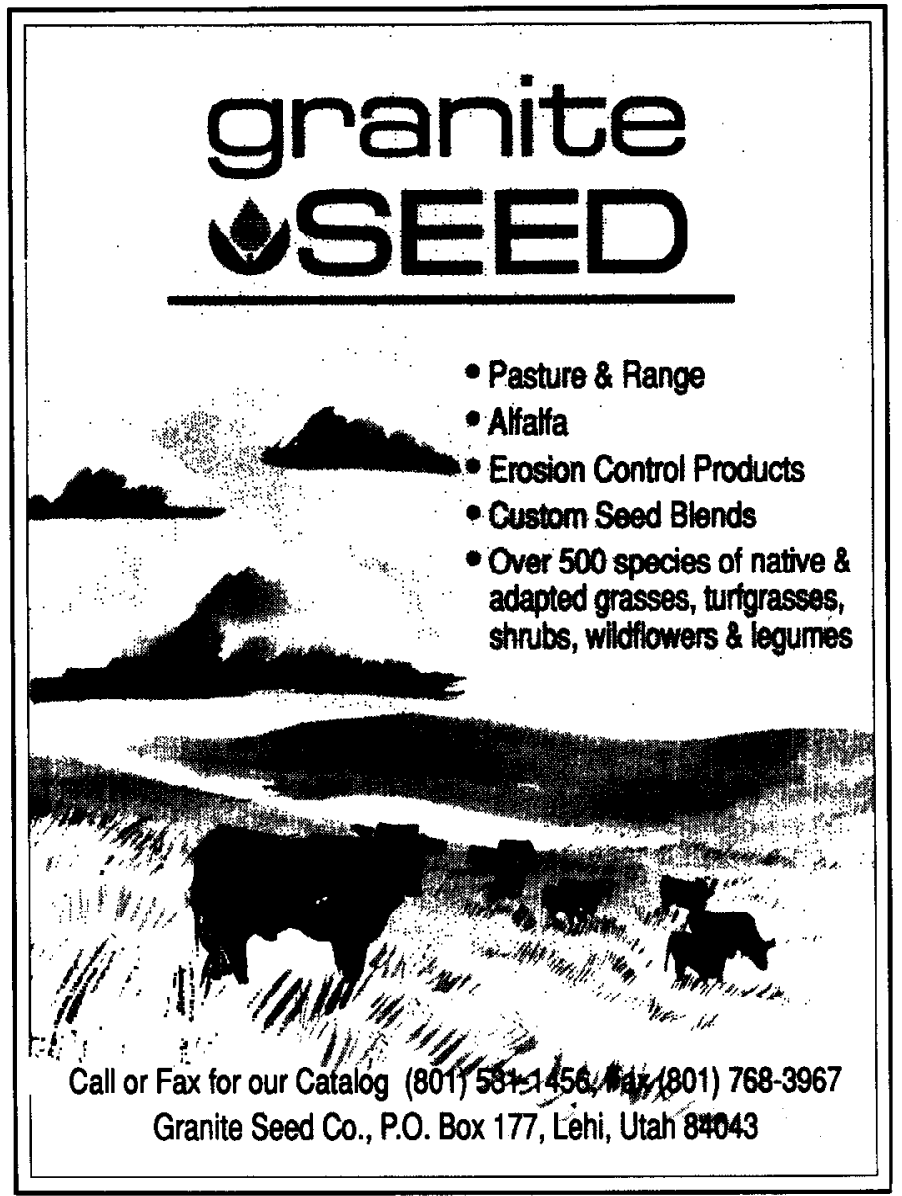

